\title{
Studies on Rootstock and Scion Parameters for Grafting in Cherry Tomatoes (Solanum lycopersicum var. cerasiforme)
}

\author{
A. T. S. Sanmathi Naik*, Shivanand Hongal, M. Anjanappa, \\ J. S. Aravinda Kumar, Ashok, K. Chandan and M. Harshavardhan
}

${ }^{1}$ Department of Vegetable Science, ${ }^{4}$ Department of Crop Physiology, ${ }^{5}$ Department of PostHarvest technology, ${ }^{6}$ Department of Floriculture and Landscape Architecture, College of Horticulture, Sirsi, Uttara Kannada, Karnataka, India ${ }^{2}$ Department of Vegetable Science, College of Horticulture, Kolar, Karnataka, India ${ }^{3}$ Department of Vegetable Science, College of Horticulture, Mysore, Karnataka, India

*Corresponding author

\section{A B S T R A C T}

Ke y w o r d s
Grafting,
Rootstock, Scion
Article Info
Accepted:
04 November 2020
Available Online:
10 December 2020

\section{Introduction}

Cherry tomato (Solanum lycopersicum var. cerasiforme) is a small garden variety of tomato having a chromosome number of $2 \mathrm{n}=24$, present days cultivated tomato (Solanum lycopersicum) is originated from it (Rick, 1969). It is a typical day-neutral and highly self-pollinated crop. It is having an indeterminate growth habit. Botanically the fruit is a berry, flower is perfect and
The experiment was conducted to study the rootstock and scion parameters of the seeds used for grafting. The cultivated and wild species of tomato and brinjal are used as rootstocks. Hybrid cherry tomato varieties like Cheramy and Sheeja are used as scion. A significant difference was recorded for the rootstock and scion parameters, among all the treatments hybrid Cheramy has taken minimum number of days to germinate. In case of days taken to reach grafting stage, among the scion materials cherry tomato hybrids has took a very less number of days to attain grafting stage and among of rootstocks, Arka Neelkanth has took minimum number of days to reach grafting stage whereas wild rootstock of brinjal has taken the maximum number of days. Stem girth of the rootstock and scions were measured at the stage of grafting, they ranged between 3.83 to $4.34 \mathrm{~mm}$. 
puree, powder, paste, rasam, and sandwiches (Anon, 2009a).

A crucial step in successful production of grafted vegetables is the selection of the compatible and economically viable rootstock and scion cultivars. The scion cultivar is selected based on seed purity, seed viability, yield, fruit quality and market demand, while the rootstocks are selected based on seed purity, seed viability, resistance to biotic and abiotic stress and compatibility with scion. (Bie et al., 2017)

The private seed producing companies and public institutes have released many varieties and hybrids with particular characteristics like high yielding, enhanced fruit quality, tolerance to biotic and abiotic stress etc. But we may not have all these characters in a single variety or hybrids, so, we can go for grafting where the best characters of both scion and rootstock could efficiently utilized. The selection of particular rootstock and scion material depends on purpose of grafting, environmental conditions and objective of experiment.

\section{Materials and Methods}

The present experiment titled "Studies on rootstock and scion parameters for grafting in Cherry tomatoes (Solanum lycopersicum var. cerasiforme)" was conducted at Research Block, Department of Vegetable Science, College of Horticulture, Sirsi, Uttara Kannada during the year 20192020. The experiment was laid out with three replications in a completely randomized block design. In this research, we used 8 rootstocks (Consist of brinjal rootstocks like Ponny, Surya, Haritha, Arka Neelkanth and Solanum torvum, the tomato rootstocks like Anagha, Abhilash and Solanum pimpenellifolium) and two commercial cherry tomato hybrids (Cheramy and Sheeja) as scion. Nursery was raised in plastic pro-trays filled with cocopeat and trichoderma. The observations regarding rootstock and scion parameters were recorded.

\section{Results and Discussion}

\section{Rootstock and scion parameters}

\section{Days taken for seed germination}

Days taken for seed germination in hybrids, varieties and wild species of tomato and brinjal used in the present study showed a significant difference presented in Table 1. A mean number of days required for seed germination ranged from 6.33 to 24.33 days, Cheramy $\left(\mathrm{T}_{10}\right)$ has taken a minimum number of days (6.33 days) it was on par with Sheeja ( $\left.\mathrm{T}_{9}\right)$ (7.00 days) and Arka Neelkanth $\left(\mathrm{T}_{5}\right)$ (7.66 days) and the wild Solanum torvum $\left(\mathrm{T}_{6}\right)$ has taken a maximum number of days (24.33 days) to germinate. From this result we can infer that, hybrid and cultivated varieties have taken less number of days to germinate, when compared with wild species. It may be due to their vigor and soft seeded character. Similar results were found in the findings of Dhivya et al., (2013).

The wild species of brinjal, Solanum torvum has taken the maximum number of days to germinate. Since Solanum torvum is a wild species with hard seed coat and prolonged dormancy of seeds that can lead to unpredictable, low and late germination. This outcome was in accordance with Ibrahim et al., (2001), Dhivya et al., (2013). Further Rathod (2017), Praveen (2019) and Sudesh (2019) also found that wild Solanum torvum has taken maximum number of days to germinate compared to the cultivated and hybrid varieties of brinjal.

The hybrid seeds are highly vigorous hence those seeds will germinate very fast but the 
wild species seeds will be dormant they will take more number of days to germinate. The success of grafted plants depends on the stem girth of the rootstock and scion material. So it is required to evaluate the number of days taken for seed germination in scion and rootstock seeds, in order to match the stem girth of rootstock and scion during grafting by which the sowing date of seeds can be adjusted to get higher graft success.

\section{Days taken to reach grafting stage}

The data regarding days taken to reach the grafting stage for all hybrids, varieties and wild species of selected rootstock and scions revealed a significantly different, presented in Table 1 . Cheramy $\left(T_{10}\right)$ has taken a minimum number of days (33 days) followed by Sheeja ( $\mathrm{T}_{9}$ ) (34.33 days) while the wild Solanum torvum $\left(\mathrm{T}_{6}\right)$ has taken a maximum number of days (87.66 days) to reach grafting stage.

In this study we observed that, among the scion materials cherry tomato hybrids has took a very less number of days to attain grafting stage. It may be due the high vigor of the hybrid seeds. In case of rootstocks, Arka Neelkanth has took minimum number of days to reach grafting stage whereas wild rootstock of brinjal has taken the maximum number of days to reach grafting stage because of its dormant seed nature, late germination and slow growth rate. These results are parallel with the reports of Rathod (2017), Sudesh (2019) and Praveen (2019).

Table.1 Days taken for seed germination, days taken to reach grafting stage and stem girth at the stage of grafting in hybrids, cultivated varieties and wild species of Cherry tomato hybrids,

\section{brinjal and tomato}

\begin{tabular}{|c|c|c|c|}
\hline Treatments & $\begin{array}{c}\text { Days taken for } \\
\text { seed germination }\end{array}$ & $\begin{array}{l}\text { Days taken to reach } \\
\text { grafting stage }\end{array}$ & $\begin{array}{l}\text { Stem girth at the stage } \\
\text { of grafting }(\mathrm{mm})\end{array}$ \\
\hline$T_{1}$ : Haritha & 8.33 & 45.00 & 3.83 \\
\hline$T_{2}$ : Ponny & 10.00 & 42.66 & 3.86 \\
\hline$T_{3}$ : Surya & 10.33 & 44.33 & 3.89 \\
\hline $\mathbf{T}_{4}$ : Anagha & 9.66 & 57.33 & 4.34 \\
\hline$T_{5}:$ Arka Neelkanth & 7.66 & 40.66 & 3.89 \\
\hline $\mathrm{T}_{6}:$ Solanum torvum & 24.33 & 87.66 & 3.80 \\
\hline $\begin{array}{l}\mathrm{T}_{7}: \text { Solanum } \\
\text { pimpenellifolium }\end{array}$ & 10.33 & 65.33 & 4.18 \\
\hline$T_{8}$ : Abhilash & 10.00 & 55.66 & 4.28 \\
\hline$T_{9}:$ Sheeja & 7.00 & 34.33 & 3.83 \\
\hline$T_{10}$ :Cheramy & 6.33 & 33.00 & 3.89 \\
\hline SEm \pm & 0.279 & 1.32 & 0.06 \\
\hline CD @ $5 \%$ & 0.823 & 3.90 & 0.19 \\
\hline CV \% & 4.645 & 4.53 & 2.91 \\
\hline
\end{tabular}




\section{Stem girth at the stage of grafting}

Stem girth of rootstock and scion is one of the critical factors for successful graft combination. The rootstock and scion must be selected based on the similarity in their stem girth. In general rootstocks with larger diameter than the scion is more desirable, as the pressure increases a solution flows from a larger diameter pipe to a smaller diameter pipe, creating a rapid distribution of these solutes over the entire plant structure, resulting in a positive interaction between the various rootstock and scion material according to fluid mechanics (Franco et al., 2018). So knowing the stem girth of rootstocks and scions is very important in vegetable grafting.

In this experiment, the stem girth at the grafting stage for hybrids, cultivated varieties, and wild species of all selected rootstock and scion materials showed a significant difference, given in Table: 1 . Solanum torvum $\left(\mathrm{T}_{6}\right)$ had the lowest stem girth $(3.80 \mathrm{~mm})$ followed by Sheeja and Haritha ( $\mathrm{T}_{9}$ and $\mathrm{T}_{1}$ ) $(3.83 \mathrm{~mm})$ whereas Anagha had the highest stem girth $(4.34 \mathrm{~mm})$ at the stage of grafting. So while selecting the rootstock and scion for grafting it is important to select them according to their stem girth for higher graft success. Higher stem girth at the stage of grafting was observed in the tomato rootstocks it may be due their genetic material. The wild species recorded less stem girth at the stage of grafting it may be attributed to its slower growth rate. These results are opposite to the findings of Praveen (2019) where higher stem girth was recorded in wild species, it may be due to variable environmental condition and seed source. It is essential to select the rootstock and scion according to their stem girth, which can be done by adjusting the sowing time of rootstock and scion to get relative stem girth at the stage of grafting, so planning is very important in grafting.
In conclusion, Hybrid variety Cheramy (6.33) took a minimum number of days and the wild Solanum torvum (24.33) took a maximum number of days to germinate.

Among the scions cherry tomato hybrids has taken a very less number of days (33-34 days) to reach grafting stage. In case of rootstocks, Arka Neelkanth has took (40.66 days) minimum number of days to reach grafting stage whereas wild rootstock of brinjal that is Solanum torvum has taken the (87.66) maximum number of days to reach grafting stage.

Stem girth of the rootstock and scion materials was recorded at the grafting stage, stem girth were in the range of 3.83 to 3.89 $\mathrm{mm}$ in the scion hybrids. In case of brinjal and tomato rootstocks stem girth ranged between 3.80 to $3.89 \mathrm{~mm}$ and 4.18 to 4.34 $\mathrm{mm}$ respectively.

\section{References}

Anonymous, 2009a, Botanical classification of cherry tomato. (www.wikipedia.com).

Anonymous, 2009b, Cherry tomato nutrition information; USDA National Nutrient Database for Standard Reference. (www.loseweight-with-us.com/cherrytomato-nutrition.html).

Bie, Z. H., Nawaz, M. A., Huang, Y.U.A.N., Lee, J. M. and Colla, G., 2017, Vegetable Grafting: Principles and Practices. Wallingford, UK. CABI: 121.

Dhivya, R., 2013, Screening studies of wild rootstocks for biotic stresses and its performance on grafting in Tomato (Solanum lycopersicon L.), Ph. D. (Hort.) Thesis, Tamil Nadu Agricultural University, Coimbatore, Tamil Nadu.

Franco, D. A., Arango, J. F., Hurtado-Salazar, A. and Ceballos-Aguirre, N., 2018, 
Development, production, and quality of 'Chonto' type tomato grafted on cherry tomato introductions. Revista Ceres., 65(2): 150-157.

Ibrahim, M., Munira, M.K., Kabir, M.S., Islam, A.K.M.S. and Miah, M.M.U., 2001, Seed germination and graft compatibility of wild Solanum as rootstock of tomato. J. of Bio. Sci., 1(8): 701-703.

Praveen, N. R., 2019, Evaluation of different brinjal (Solanum melongena L.) grafts for bacterial wilt resistance, M.Sc. (Hort) Thesis, College of Horticulture, Bengaluru, University of Horticultural Sciences, Bagalkot. (India).

Rathod, T., 2017, Evaluation of rootstocks and scion in Brinjal, monitoring the changes induced by different rootstock-scion combinations in terms of plant growth and fruit quality. M.Sc. (Hort.) Thesis, Dr. Y. S. R. Horticultural university, College of horticulture, Venkataramannagudem, West Godavari. (India).

Rick, C.M., 1969, Origin of cultivated tomato and status of the problem. Internat. Bot. 59-68.

Sudesh, K.S., 2019, Evaluation of Brinjal (Solanum melongena L.) grafts for growth, yield and yield attributing characters, M.Sc. (Hort.) Thesis, College of Horticulture, Bengaluru, University of Horticultural Sciences, Bagalkot. (India).

\section{How to cite this article:}

Sanmathi Naik, A. T. S., Shivanand Hongal, M. Anjanappa, J. S. Aravinda Kumar, Ashok, K. Chandan and Harshavardhan, M. 2020. Studies on Rootstock and Scion Parameters for Grafting in Cherry Tomatoes (Solanum lycopersicum var. cerasiforme) Int.J.Curr.Microbiol.App.Sci. 9(12): 24-28. doi: https://doi.org/10.20546/ijcmas.2020.912.005 